\title{
Regulatory cells, cytokine pattern and clinical risk factors for asthma in infants and young children with recurrent wheeze
}

\author{
L. M. Borrego*, M. J. Arroz ${ }^{\dagger}$, P. Videira ${ }^{\dagger}$, C. Martins ${ }^{\dagger}$, H. Guimarães ${ }^{\dagger}$, G. Nunes ${ }^{\dagger}$, A. L. Papoila ${ }^{\ddagger}$ and H. Trindade ${ }^{\dagger}$ \\ * Serviço de Imunoalergologia, Centro Hospitalar Lisboa Central - Hospital de Dona Estefânia, Rua Jacinta Marto, Lisboa, Portugal, †'Departamento de Imunologia, da \\ Faculdade de Ciências Médicas, da Universidade Nova de Lisboa, Campo dos Mártires da Pátria, Lisboa, Portugal and ${ }^{\ddagger}$ Departamento de Bioestatística, da Faculdade \\ de Ciências, Médicas da Universidade Nova de Lisboa, Campo dos Mártires da Pátria, Lisboa, Portugal
}

\section{Clinical \&t Experimental Allergy}

\section{Correspondence:}

Dr Luis Miguel Borrego, Serviço de Imunoalergologia, Centro Hospitalar Lisboa Central - Hospital de Dona Estefania, Rua Jacinta Marto, 1169-045 Lisboa, Portugal.

E-mail:miguel.borrego@sapo.pt Cite this as: L. M. Borrego, M. J. Arroz, P. Videira, C. Martins, H. Guimarães, G. Nunes, A. L. Papoila and H. Trindade, Clinical \& Experimental Allergy, 2009 (39) 1160-1169.

\section{Summary}

Background Several risk factors for asthma have been identified in infants and young children with recurrent wheeze. However, published literature has reported contradictory findings regarding the underlying immunological mechanisms.

Objectives This study was designed to assess and compare the immunological status during the first 2 years in steroid-naïve young children with $\geqslant$ three episodes of physician-confirmed wheeze $(n=50)$, with and without clinical risk factors for developing subsequent asthma (i.e. parental asthma or a personal history of eczema and/or two of the following: wheezing without colds, a personal history of allergic rhinitis and peripheral blood eosinophilia $>4 \%$ ), with age-matched healthy controls $(n=30)$.

Methods Peripheral blood $\mathrm{CD}^{+}{ }^{+} \mathrm{CD} 25^{+}$and $\mathrm{CD} 4^{+} \mathrm{CD} 25^{\text {high }} \mathrm{T}$ cells and their cytotoxic T-lymphocyte-associated antigen-4 (CTLA-4), GITR and Foxp3 expression were analysed by flow cytometry. Cytokine (IFN- $\gamma$, TGF- $\beta$ and IL-10), CTLA-4 and Foxp3 mRNA expression were evaluated (real-time PCR) after peripheral blood mononuclear cell stimulation with phorbol 12-myristate 13-acetate (PMA) (24 h) and house dust mite (HDM) extracts (7th day). Results Flow cytometry results showed a significant reduction in the absolute number of $\mathrm{CD} 4{ }^{+} \mathrm{CD} 25^{\text {high }}$ and the absolute and percentage numbers of $\mathrm{CD} 4{ }^{+} \mathrm{CD} 25^{+} \mathrm{CTLA}-4^{+}$in wheezy children compared with healthy controls. Wheezy children at a high risk of developing asthma had a significantly lower absolute number of $\mathrm{CD} 4{ }^{+} \mathrm{CD} 25^{+}(P=0.01)$ and $\mathrm{CD} 4{ }^{+} \mathrm{CD} 25^{\text {high }}(P=0.04)$, compared with those at a low risk. After PMA stimulation, CTLA-4 $(P=0.03)$ and Foxp3 $(P=0.02)$ expression was diminished in wheezy children compared with the healthy children. After HDM stimulation, CTLA-4 $(P=0.03)$ and IFN- $\gamma(P=0.04)$ expression was diminished in wheezy children compared with healthy children. High-risk children had lower expression of IFN $-\gamma(P=0.03)$ compared with low-risk and healthy children and lower expression of CTLA-4 $(P=0.01)$ compared with healthy children. Conclusions Although our findings suggest that some immunological parameters are impaired in children with recurrent wheeze, particularly with a high risk for asthma, further studies are needed in order to assess their potential as surrogate predictor factors for asthma in early life.

Keywords asthma, child, cytokine, regulatory cells, wheezing

Submitted 27 September 2008; revised 19 February 2009; accepted 24 February 2009

\section{Introduction}

Recurrent wheeze is a common symptom during infancy and early childhood [1, 2]. Although the majority of children will outgrow their symptoms, some go on to develop asthma [3, 4]. A clinical index devised by CastroRodriguez et al. [5] considers young children with recur- rent wheezing in the first 3 years of life to be at a high risk of developing asthma if there is a parental history of asthma or a personal history of eczema, or if two of the following are present: a personal history of allergic rhinitis (AR), wheezing without colds and/or peripheral blood eosinophilia $>4 \%$. Allergic asthma is a chronic inflammatory disorder characterized by a T-helper type 2 
(Th2) immune response (e.g. IL-4, IL-5, IL-10 and IL-13) [6]. Moreover, it has been suggested by some studies that decreased IFN- $\gamma$ levels are associated with atopic diseases [7-10]. The increase of both Th2-associated allergic diseases and Th1 (e.g. IFN- $\gamma$ and TNF- $\alpha$ )-associated autoimmune diseases has prompted the hypothesis that these conditions might result from a functional or a quantitative deficiency of regulatory T cells (Treg) that control Th1 and Th2 immune responses [11-13]. CD $4{ }^{+} \mathrm{CD} 25^{+}$Treg cells constitute $5-10 \%$ of the total $\mathrm{CD} 4^{+} \mathrm{T}$ cells. These cells can be generated in the thymus or in the periphery and reside in blood and other lymphoid tissues [11-14]. They have the ability to inhibit cytokine production and the proliferation of $\mathrm{CD} 4{ }^{+} \mathrm{CD} 25^{-}$effector $\mathrm{T}$ cells in a contactdependent fashion [15-16]. TGF- $\beta 1$ and cytotoxic T-lymphocyte-associated antigen-4 (CTLA-4) appear to be essential for their suppressive activity [17-21]. Activated and regulatory $\mathrm{CD} 4^{+} \mathrm{T}$ cells might have overlapping expressions of $\mathrm{CD} 25$ and hence it has been suggested that selection of the $\mathrm{CD} 4{ }^{+} \mathrm{CD} 25^{\text {high }}$ subset of $\mathrm{CD} 4^{+} \mathrm{CD} 25^{+}$may minimize this contaminating effect. $\mathrm{CD} 4{ }^{+} \mathrm{CD} 25^{\text {high }}$ represents $2 \%$ of the total $\mathrm{CD} 4^{+} \mathrm{T}$ cells and has been considered to be the truly regulatory population, expressing the forkhead winged helix transcription factor Foxp 3 [22-26].

The primary aim of this study was to assess whether the population of regulatory cells was reduced during the first 2 years of life in recurrently wheezy children with a high risk of developing subsequent asthma [5] when compared with age-matched 'low-risk' wheezing children and healthy controls. For this purpose, Treg were studied using flow cytometry. The secondary aim was to evaluate whether recurrently wheezy children with a high risk of developing asthma have a different cytokine pattern, when compared with the two subgroups of children (low risk for asthma and healthy). In order to evaluate mRNA expression for cytokines, CTLA-4 and Foxp3, reverse transcription and real-time PCR techniques were applied.

\section{Methods}

\section{Study population}

Infants and young children $(n=50)$ aged between 8 and 20 months, with recurrent wheeze (defined as $\geqslant 3$ episodes of medically diagnosed wheeze) but before receiving any inhaled corticosteroids or anti-leukotrienes, were recruited from the out-patient clinic in Hospital Dona Estefania, Lisbon (September 2005 to September 2007). They were stratified as having a high or a low risk of developing asthma according to the clinical index developed by Castro-Rodriguez et al. [5]. According to their classification, high-risk children had a parental history of asthma or a personal history of eczema, and/or two of the following: a personal history of AR, wheezing without colds and/or peripheral blood eosinophilia $>4 \%$. Agematched healthy children $(n=30)$ without any prior history of lower respiratory illness or wheeze, a personal history of allergic disorders (food allergy, eczema, rhinitis) or parental asthma were recruited from local medical clinics and from those attending routine screening appointments at the Ear, Nose and Throat (ENT) Department within the same hospital. All children were born with 37 or more completed gestational weeks with birth weight $>10$ th percentile. Children with cardiac, metabolic, neurological or gastrointestinal diseases and upper airway pathology were excluded from the study. The Ethics Committee approved the study and parents of participating children gave informed written consent.

\section{Flow cytometric analysis}

Peripheral blood was analysed by four-colour Flow Cytometry (BD FACSCalibur, BD Biosciences, San Jose, CA, USA). To determine $T$ cell subsets and evaluate CTLA-4 and GITR expression in $\mathrm{CD}^{+} \mathrm{CD} 25^{+} \mathrm{T}$ cells, $100 \mu \mathrm{L}$ aliquots of whole blood were stained with mouse antihuman monoclonal antibodies (mAbs) conjugated with fluorescent dyes: anti-CD3-FITC, anti-CD8-PE, anti-CD4PerCP Cy5.5 (BD Biosciences), anti-CTLA-4-FITC, antiGITR/TNFRSF18-APC (RD, Minneapolis, MN, USA) and anti-CD25-PE (Immunostep, Salamanca, Spain). The incubation period lasted for $15 \mathrm{~min}$ in the dark at room temperature. Each sample was lysed with $2 \mathrm{~mL}$ of BD FACS Lysing Solution (BD Biosciences) for $10 \mathrm{~min}$, and then washed with $2 \mathrm{~mL}$ of BD FACS Flow (BD Biosciences). Foxp3 expression in $\mathrm{CD}^{+} \mathrm{CD} 25^{+}$Tcells was studied using the Human Treg staining Kit (eBioscience, San Diego, CA, USA), which included anti-CD4-FITC, antiFoxp3-PE, anti-CD25-APC and IgG2a PE as an isotype control. Intracellular staining for Foxp3 was performed according to the manufacturer's instructions. Cell Quest $3.3^{\mathrm{TM}}$ (BD Biosciences) software was used for both acquisition and analysis. A combined Boolean gating for lymphocytes (SSC/FSC) and $\mathrm{T}$ helper lymphocytes (CD4 ${ }^{\text {high }} / \mathrm{SSC}$ ) was used. At least $20000 \mathrm{CD} 4^{+} \mathrm{T}$ cells were acquired in order to obtain enough $\mathrm{CD}^{+} \mathrm{T}$ regulatory cells for accurate evaluation. $\mathrm{CD} 4^{+} \mathrm{CD} 25^{\text {high }} \mathrm{T}$ cells were defined as $\mathrm{CD} 4^{+} \mathrm{T}$ cells with a fluorescence intensity for CD25 of $>1 \times 10^{2}$ on a logarithmic scale, which appeared as a cluster above the population containing $\mathrm{CD} 4{ }^{+} \mathrm{CD} 25^{\text {low }}$ and $\mathrm{CD} 4{ }^{+} \mathrm{CD} 25^{-}$, according to BaecherAllan et al. [22, 27]. CTLA-4 and GITR expressions were determined in $\mathrm{CD} 4{ }^{+} \mathrm{CD} 25^{+} \mathrm{T}$ cells. The Foxp3 expression was determined in both $\mathrm{CD} 4^{+}$and $\mathrm{CD} 4^{+} \mathrm{T}$ cells with $\mathrm{CD} 25$ expression. Results were presented as a percentage of total lymphocytes and as absolute cell counts (cells/ $\mu \mathrm{L}$ ), which were obtained using a double platform. 


\section{Cell culture}

Peripheral blood mononuclear cells (PBMC) were isolated from heparinized blood samples using the Ficoll gradient centrifugation, for $20 \mathrm{~min}$ at $1200 \mathrm{~g}$ (Lymphoprep $^{\mathrm{TM}}$, AXIS-SHIELD PoC AS, Oslo, Norway), then washed twice in RPMI-1640 medium with 25 mM HEPES buffer solution, and re-suspended at $1 \times 10^{6}$ cells/mL in RPMI-1640 medium supplemented with $0.1 \mathrm{~mm}$ non-essential amino acids, $2 \mathrm{~mm}$ L-glutamine, $1 \mathrm{~mm}$ sodium piruvate, $0.5 \mu \mathrm{m} 2$-mercaptoethanol, $0.1 \mathrm{mg} / \mathrm{mL}$ streptomycin, $100 \mathrm{U} / \mathrm{mL}$ penicillin and 10\% v/v heat-inactivated fetal calf serum. Cells were seeded in 48-well microtitre plates $\left(4 \times 10^{5}\right.$ cells/ well), and stimulated with $1 \mu \mathrm{g} / \mathrm{mL}$ phorbol 12 -myristate 13-acetate (PMA) (Sigma-Aldrich, St Louis, MO, USA) and $2.5 \mu \mathrm{g} / \mathrm{mL}$ ionomycin or a mixture of house dust mite (HDM) Dermatophagoides pteronyssinus (Der p 1) (100 ng/ $\mathrm{mL}$ ) and Dermatophagoides farinae (Der f 1) (100 ng/mL). Incubation occurred at $37^{\circ} \mathrm{C}$ in a humidified atmosphere with $5 \% \mathrm{CO}_{2}$ for $24 \mathrm{~h}$ (PMA+ionomycin) or 7 days (Der $\mathrm{p} 1$ and Der f 1 media mixture). Controls with non-stimulated cells were incubated under the same conditions for both periods. After incubation, cells were re-suspended in culture medium, placed into identified microtubes and centrifuged at $1000 \mathrm{~g}$ for $5 \mathrm{~min}$ at $4{ }^{\circ} \mathrm{C}$. Each pellet was re-suspended in RNA later ${ }^{\circledR}$ (Sigma-Aldrich), and stored at $-20{ }^{\circ} \mathrm{C}$.

\section{Extraction of RNA and reverse transcription}

Total mRNA was isolated from the cell pellets using the GenElute $^{\circledR}$ Mammalian Total RNA kit (Sigma-Aldrich), according to the manufacturer's instructions, and quantified using a UV1101 - Biotech spectrophotometer (WPA, Cambridge, UK). A260-A280 ratios were also measured and only samples with A260/A280 ratios between 1.9 and 2.1 were considered. One microgram of RNA from each sample was reverse transcribed to cDNA using the High Capacity cDNA Archive Kit (Applied Biosystems, Foster City, CA, USA) reagent, according to the manufacturer's instructions.

Quantitative polymerase chain reaction for cytotoxic $T$ lymphocyte-associated antigen-4, Foxp3, interferon- $\gamma$, transforming growth factor- $\beta$ and interleukin-10

Real-time PCR was performed in a 7500 Fast Real Time system (Applied Biosystems) using Taqman PCR Universal Master Mix ${ }^{\circledR}$, primers and Taqman probes for CTLA-4, Foxp3, IFN- $\gamma$, TGF- $\beta$ and IL-10 genes provided by Applied Biosystems, according to the manufacturer's instructions. Real-time PCR reactions were performed in duplicate for each gene and for the housekeeping gene ( $\beta$-actin), as well as negative control reactions (without any cDNA added) with each primer and a probe. Reaction mixtures were subjected to 40 reaction cycles. Fluorescence detection and normalization during the PCR reaction was controlled using the ABI SDS v2.3 software. For each individual gene, the respective comparative threshold cycle $\left(C_{\mathrm{T}}\right)$ was calculated and the relative expression of the gene was normalized to the corresponding $\beta$-actin mRNA level. The mRNA relative expression level for each gene was determined using the $2^{-\Delta \Delta C_{T}}$ formula according to the $C_{\mathrm{T}}$ method described by Livak and Schmittgen [28]. Differences between the gene expression in the stimulated cultures and the gene expression in the respective non-stimulated cultures were presented as $-\Delta \Delta C_{\mathrm{T}}[29]$.

\section{Statistical analysis}

Depending on the distributions of the results, values were either reported as mean \pm SEM or median and interquartile range $\left(\mathrm{P}_{25} ; \mathrm{P}_{75}\right)$, and were presented as box and whiskersplots with outliers. Statistical data analysis was performed using the SPSS software (Statistical Package for the Social Sciences), version 15.0 for Windows. Flow cytometric data, as well as mRNA expression data, were statistically compared between healthy and wheezy children using the Student's $t$-test or the Mann-Whitney $U$-test (whenever variable distributions were not normal). Subgroup comparisons to determine statistically significant differences were performed by either ANOVA I (variance analysis) or the Kruskal-Wallis test, whenever ANovA I could not be used. The least significant difference (LSD) test was applied to ranks when significant statistical differences were detected between subgroups. The associations between laboratory parameters and recurrent wheeze were also investigated using univariate and multiple linear regression analyses. Statistical significance was defined by a $P$-value of $<0.05$.

\section{Results}

\section{Characteristics of the study participants}

Eighty children participated in this study and were classified as mentioned above. In the index group, 50 wheezy young children, who were steroid naïve, were further divided into two at-risk groups for developing subsequent asthma: low risk $(n=33)$ and high risk $(n=17)$. The control group comprised 30 age-matched healthy children who had no prior history of lower respiratory illness or wheeze. Immunological assessments using the flow cytometer were made using blood samples obtained from all children, together with determination of cytokine expression. At the time of immunological measurement, infants were free of respiratory symptoms or illness for at least 3 weeks. No significant differences were found between children participating in the study regarding age, sex and smoke 
exposure during pregnancy (Table 1). Among the wheezy children, $13(26 \%)$ had a parental history of asthma, three (6\%) had a personal history of eczema, seven (14\%) had a personal history of AR, $21(42 \%)$ had wheezing without colds and $14(28 \%)$ had peripheral blood eosinophilia $>4 \%$. In the high-risk group, $13(76 \%)$ had a parental history of asthma, three $(18 \%)$ had a personal history of eczema, five $(29 \%)$ had a personal history of rhinitis, 12 (71\%) had wheezing without colds and nine (53\%) had peripheral blood eosinophilia $>4 \%$. In the low-risk

Table 1. Anthropometric data comparisons between wheezing and healthy children

\begin{tabular}{lccl}
\hline & $\begin{array}{l}\text { Wheezy children } \\
(n=50)\end{array}$ & $\begin{array}{l}\text { Healthy children } \\
(n=30)\end{array}$ & $P$-value \\
\hline $\begin{array}{l}\text { Male, } n(\%)^{*} \\
\begin{array}{c}\text { Maternal smoking during } \\
\text { pregnancy, } n(\%)\end{array}\end{array}$ & $14(62 \%)$ & $22(73 \%)$ & 0.4 \\
$\begin{array}{l}\text { Age, weeks } \\
\dagger\end{array}$ & $63.2(16.6)$ & $66.2(16.7)$ & 0.4 \\
\hline
\end{tabular}

${ }^{*}$ Results expressed as $n(\%)-\chi^{2}$ test.

${ }^{\dagger}$ Results expressed as mean (SD) - Student's $t$-test. group, two (6\%) had a personal history of rhinitis, nine $(27 \%)$ had wheezing without colds and five (15\%) had peripheral blood eosinophilia $>4 \%$.

\section{$C D 4^{+} C D 25^{+}$T cells - characterization of different subsets among study groups}

The following populations within the study groups were compared and evaluated: $\mathrm{CD}^{+} \mathrm{CD}_{25}{ }^{+} \mathrm{T}$ cells, $\mathrm{CD} 4{ }^{+} \mathrm{CD} 25^{\text {high }} \mathrm{T}$ cells, $\mathrm{CD} 4{ }^{+} \mathrm{CD} 25^{+} \mathrm{CTLA}-4^{+} \mathrm{T}$ cells, $\mathrm{CD}^{+}{ }^{+} \mathrm{CD} 25^{+} \mathrm{GITR}^{+} \mathrm{T}$ cells and $\mathrm{CD} 4{ }^{+} \mathrm{CD} 25^{\text {high }} \mathrm{Foxp}^{+}$ $\mathrm{T}$ cells. When comparing children with wheeze with healthy controls, we found significantly lower $\mathrm{CD} 4{ }^{+} \mathrm{CD} 25^{\text {high }} \mathrm{T}$ absolute cell counts in the wheezy group ( $248 \pm 87$ vs. $296 \pm 98$ cells $/ \mu \mathrm{L}, P=0.03$ ). These children also had lower absolute and percentage values for CD $4{ }^{+}$CD $25^{+}$CTLA $-4^{+}$. However, as shown in Table 2, no significant differences between the two groups were found either for the percentage of $\mathrm{CD} 4{ }^{+} \mathrm{CD} 25^{\text {high }}$-expressing cells or for the other cell populations studied (percentage or absolute values). When data were evaluated for the three different groups (high risk, low risk and healthy children), absolute numbers of $\mathrm{CD} 4{ }^{+} \mathrm{CD} 25^{+}$(527 \pm 147 vs.

Table 2. Results for $\mathrm{CD} 4{ }^{+} \mathrm{T}$ cells subsets (flow cytometry), and for relative quantification of mRNA expression after PMA stimulation (24 $\mathrm{h}$ incubation) and HDM extract stimulation (7 days incubation), in wheezy and healthy children

\begin{tabular}{|c|c|c|c|}
\hline & Wheezy children $(n=50)$ & Healthy children $(n=30)$ & $P$-value \\
\hline \multicolumn{4}{|l|}{ Flow cytometry } \\
\hline $\mathrm{Abs} \mathrm{CD} 4^{+} \mathrm{CD} 25^{+*}$ & $506(162)$ & $563(147)$ & 0.1 \\
\hline$\% \mathrm{CD}^{+} \mathrm{CD} 25^{+*}$ & $15.9(3.3)$ & $15.2(2.4)$ & 0.4 \\
\hline Abs $\mathrm{CD} 4^{+} \mathrm{CD} 25^{\mathrm{high}^{*}}$ & $248(87)$ & $296(98)$ & 0.03 \\
\hline$\% \mathrm{CD} 4^{+} \mathrm{CD} 25^{\mathrm{high}^{\dagger}}$ & $7.5(6.4 ; 8.7)$ & $7.4(6.8 ; 9)$ & 0.4 \\
\hline Abs CD $4^{+} \mathrm{CD} 25^{+}$CTLA $-4^{+^{+}}$ & $24(13 ; 43)$ & $96(35 ; 178)$ & 0.0001 \\
\hline$\% \mathrm{CD}^{+}{ }^{+} \mathrm{CD} 25^{+} \mathrm{CTLA}^{-4^{+}}{ }^{+}$ & $0.8(0.5 ; 1.3)$ & $2.8(1.0 ; 4.3)$ & 0.0001 \\
\hline Abs CD $4^{+} \mathrm{CD} 25^{+} \mathrm{GITR}^{+^{+}}$ & $12(3 ; 30)$ & $20(7 ; 38)$ & 0.2 \\
\hline$\% \mathrm{CD} 4^{+} \mathrm{CD} 25^{+} \mathrm{GITR}^{+{ }^{+}}$ & $0.3(0.1 ; 0.9)$ & $0.5(0.2 ; 0.8)$ & 0.3 \\
\hline Abs CD $4^{+} \mathrm{CD} 25^{\text {high }}$ Foxp $3^{+*}$ & $145(98)$ & $166(69)$ & 0.4 \\
\hline$\% \mathrm{CD}^{+} \mathrm{CD} 25^{\text {high }}$ Foxp $^{+*}$ & $4.4(2.7)$ & $4.5(1.6)$ & 0.9 \\
\hline \multicolumn{4}{|l|}{ mRNA expression } \\
\hline CTLA- $^{\dagger}$ (PMA 24 h) & $3.2(2.5 ; 4.2)$ & $4.7(1.5 ; 5.8)$ & 0.03 \\
\hline CTLA-4 ${ }^{\dagger}$ (HDM 7 days) & $-0.4(-1.2 ; 0.5)$ & $0.3(-0.5 ; 1.2)$ & 0.03 \\
\hline Foxp $3^{\dagger}$ (PMA 24 h) & $0.4(-0.2 ; 1.1)$ & $1.6(0.3 ; 2.1)$ & 0.02 \\
\hline Foxp3* (HDM 7 days) & $0.02(0.2)$ & $0.06(0.3)$ & 0.9 \\
\hline IFN- $\gamma^{\dagger}$ (PMA $\left.24 \mathrm{~h}\right)$ & $8.1(5.4 ; 9.7)$ & $4.8(-0.3 ; 9.5)$ & 0.09 \\
\hline IFN- $\gamma^{\dagger}$ (HDM 7 days) & $-0.5(-1.6 ; 0.3)$ & $0.2(-0.7 ; 1.7)$ & 0.04 \\
\hline IL-10* (PMA 24h) & $-1.7(0.5)$ & $-1.8(0.5)$ & 0.9 \\
\hline IL-10 ${ }^{\dagger}$ (HDM 7 days) & $-0.2(-0.8 ; 1.0)$ & $0.3(-1.3 ; 1)$ & 0.9 \\
\hline TGF- $\beta^{\dagger}$ (PMA 24 h) & $1.7(0.9 ; 2.3)$ & $1.9(0.3 ; 2.3)$ & 0.7 \\
\hline TGF- $\beta^{\dagger}$ (HDM 7 days) & $0.05(-0.5 ; 0.6)$ & $-0.2(-0.5 ; 0.7)$ & 0.9 \\
\hline
\end{tabular}

Results were calculated as described in "Methods," with gene expression values corresponding to the expression of a defined gene in a stimulated cell culture compared with non-stimulated control cells (negative and positive values indicate, respectively, decreased and increased expression of the gene).

*Results expressed as mean (SD), Student's $t$-test.

${ }^{\dagger}$ Results expressed as median $\left(\mathrm{P}_{25} ; \mathrm{P}_{75}\right)$, Mann-Whitney test.

CTLA-4; cytotoxic T-lymphocyte-associated antigen-4; HDM, house dust mite; PMA, phorbol 12-myristate 13-acetate. 
Table 3. Results for $\mathrm{CD}^{+}{ }^{+} \mathrm{T}$ cells subsets (flow cytometry), and for relative quantification of mRNA expression after PMA stimulation (24 $\mathrm{h}$ incubation) and HDM extract stimulation (7 days incubation), in HC (healthy controls), LRG (low-risk wheezy children) and HRG (high-risk wheezy children)

\begin{tabular}{|c|c|c|c|}
\hline $\begin{array}{l}\text { Abs - absolute count values } \\
\text { (cells } / \mu \mathrm{L} \text { ) } \% \text { - percentage values }\end{array}$ & $\mathrm{HRC}(n=17)$ & $\operatorname{LRC}(n=33)$ & HC $(n=30)$ \\
\hline \multicolumn{4}{|l|}{ Flow cytometry } \\
\hline Abs $\mathrm{CD} 4^{+} \mathrm{CD} 25^{+*+}$ & 425 (129) & $544(163)$ & 527 (147) \\
\hline$\% \mathrm{CD}^{+} \mathrm{CD} 25^{+*}$ & $15.9(4.9)$ & $15.9(3.2)$ & $15.2(2.4)$ \\
\hline Abs CD $4^{+} \mathrm{CD} 25^{\text {high }}{ }^{* \dagger}$ & $210(70)$ & 266 (89) & $296(98)$ \\
\hline$\% \mathrm{CD} 4^{+} \mathrm{CD} 25^{\mathrm{high}^{\ddagger}}$ & $7.31(6.2 ; 8.4)$ & $7.7(6.4 ; 8.7)$ & $7.4(6.8 ; 9)$ \\
\hline $\mathrm{Abs} \mathrm{CD} 4^{+} \mathrm{CD} 25^{+}$CTLA $-4^{+\neq \dagger}$ & $24(11 ; 43)$ & $24(14 ; 51)$ & $96(35 ; 178)$ \\
\hline$\% \mathrm{CD}^{+}{ }^{+} \mathrm{CD} 25^{+} \mathrm{CTLA}^{-4^{+\ddagger \dagger}}$ & $0.88(0.6 ; 1.3)$ & $0.76(0.4 ; 1.6)$ & $2.8(1.0 ; 4.3)$ \\
\hline Abs CD $4^{+} \mathrm{CD}_{25}{ }^{+} \mathrm{GITR}^{+\ddagger}$ & $14(5 ; 32)$ & $11(3 ; 25)$ & $20(7 ; 38)$ \\
\hline$\% \mathrm{CD}^{+}{ }^{+} \mathrm{CD} 25^{+} \mathrm{GITR}^{+\ddagger}$ & $0.40(0.2 ; 1)$ & $0.25(0.1 ; 0.8)$ & $0.5(0.2 ; 0.8)$ \\
\hline Abs CD $4^{+} \mathrm{CD} 25^{\text {high }}$ Foxp $3^{+*}$ & $121(95)$ & $156(99)$ & $164(69)$ \\
\hline$\% \mathrm{CD}^{+}{ }^{+} \mathrm{CD} 25^{\text {high }}$ Foxp3 $3^{+*}$ & $4.3(3.1)$ & $4.4(2.6)$ & $4.5(1.6)$ \\
\hline \multicolumn{4}{|l|}{ mRNA expression } \\
\hline CTLA- $4^{\ddagger}$ (PMA 24 h) & $2.9(2.3 ; 4.2)$ & $3.3(2.8 ; 4.2)$ & $4.7(1.5 ; 5.8)$ \\
\hline CTLA- $4^{\ddagger}$ (HDM 7 days) $)^{\dagger}$ & $-0.7(-1.3 ;-0.4)$ & $0.01(-0.8 ; 0.6)$ & $0.3(-0.5 ; 1.2)$ \\
\hline Foxp $3^{\ddagger}$ (PMA 24 h) & $0.4(-0.8 ; 0.7)$ & $0.4(-0.2 ; 1.1)$ & $1.6(0.3 ; 2.1)$ \\
\hline Foxp3* (HDM 7 days) & $-0.3(0.5)$ & $0.2(0.3)$ & $0.06(0.3)$ \\
\hline IFN- $\gamma^{\ddagger}($ PMA $24 \mathrm{~h})$ & $9.5(6.2 ; 10.5)$ & $7.6(5,4 ; 8.7)$ & $4.8(-0.3 ; 9.5)$ \\
\hline${\text { IFN }-\gamma^{\ddagger}(\mathrm{HDM}} 7$ days $)^{\dagger}$ & $-1.3(-1.7 ;-0.9)$ & $-0.1(-1.4 ; 0.8)$ & $0.2(-0.7 ; 1.7)$ \\
\hline IL-10* (PMA 24 h) & $-1.5(1.1)$ & $-1.9(0.6)$ & $-1.8(0.5)$ \\
\hline IL-10 & $-0.3(-0.9 ; 1.1)$ & $0.3(-0.9 ; 1,1)$ & $0.3(-1.3 ; 1)$ \\
\hline TGF- $\beta^{\ddagger}$ (PMA 24 h) & $1.6(0.9 ; 2,2)$ & $1.7(0.9 ; 2.3)$ & $1.9(0.3 ; 2.3)$ \\
\hline TGF- $\beta^{\ddagger}$ (HDM 7 days) & $0.2(-0.2 ; 0.7)$ & $-0.2(-1.1 ; 0.5)$ & $-0.2(-0.5 ; 0.7)$ \\
\hline
\end{tabular}

Values were calculated as described in "Methods," with gene expression values corresponding to the expression of a defined gene in a stimulated cell culture compared with non-stimulated control cells (negative and positive values indicate, respectively, decreased and increased expression of the gene). *Results expressed as mean (SD). Group comparisons with ANova.

${ }^{\dagger}$ Group comparisons for all parameters with statistically significant differences between groups are shown in Fig. 1a-f.

${ }^{\ddagger}$ Results expressed as median $\left(\mathrm{P}_{25} ; \mathrm{P}_{75}\right)$. Group comparisons with Kruskall-Wallis test.

CTLA-4, cytotoxic T-lymphocyte-associated antigen-4; HDM, house dust mite; PMA, phorbol 12-myristate 13-acetate.

$425 \pm 129$ cells $/ \mu \mathrm{L}, P=0.004)$ and $\mathrm{CD} 4{ }^{+} \mathrm{CD} 25^{\text {high }} \mathrm{T}$ cells ( $296 \pm 98$ vs. $210 \pm 70$ cells $/ \mu \mathrm{L}, P=0.002$ ) were significantly higher in the healthy group compared with the high-risk group. However, no significant differences were observed between healthy and low-risk children. $\mathrm{CD} 4{ }^{+} \mathrm{CD} 25^{+}$and $\mathrm{CD} 4{ }^{+} \mathrm{CD} 25^{\text {high }}$ percentage values presented no significant differences between the three groups. Children from the high-risk group also exhibited lower absolute counts for both $\mathrm{CD} 4^{+} \mathrm{CD} 25^{+}$and $\mathrm{CD} 4^{+} \mathrm{CD} 25^{\text {high }}$ populations when compared with the low-risk group (Table 3 and Fig. 1). Different findings were obtained with the $\mathrm{CD} 4{ }^{+} \mathrm{CD} 25^{+}$CTLA $-4^{+}$population: both the high- and the low-risk wheezy children had lower values for percentage and absolute numbers in comparison with healthy chil- dren. However, between high- and low-risk groups, no significant differences in the absolute and percentage values of the $\mathrm{CD} 4{ }^{+} \mathrm{CD} 25^{+} \mathrm{CTLA}-4^{+}$population were found. For the other populations studied (Tables 2 and 3), no statistically significant differences were found between groups although there was a tendency towards higher values in healthy children.

\section{Cytokines, cytotoxic T-lymphocyte-associated antigen-4 and Foxp 3 expression post-phorbol 12-myristate 13- acetate stimulation}

After the 24-h incubation period for cell cultures stimulated with PMA, the values for the healthy group showed

Fig. 1. (a)-(f). Group comparisons for parameters with statistically significant differences between groups: (a) $\mathrm{CD} 4^{+} \mathrm{CD} 25^{+}$absolute values, (b) $\mathrm{CD} 4{ }^{+} \mathrm{CD} 25^{\text {high }}$ absolute values, (c) $\mathrm{CD} 4{ }^{+} \mathrm{CD} 25^{+}$CTLA- ${ }^{+}$absolute values, (d) $\mathrm{CD} 4{ }^{+} \mathrm{CD} 25^{+}$CTLA- $4^{+}$percentage values, (e) CTLA-4 relative expression, ${ }^{\$}$ (f) INF- $\gamma$ relative expression. ${ }^{\S}$ The median is represented by the black bar; the lower and upper bounds of the box represent the 25 th and 75 th percentile; the whiskers represent the 5th and 95th percentiles; and outliers are represented as circles/asterisks outside the whiskers. HC, healthy children; LRC, low risk for asthma wheezing children; HRC, high risk for asthma wheezing children. "Values were calculated as described in "Methods" and correspond to the gene in an house dust mite-stimulated cell culture compared with non-stimulated control cells (negative and positive values indicate, respectively, decreased and increased expression of the gene). CTLA, cytotoxic T-lymphocyte-associated antigen-4. 

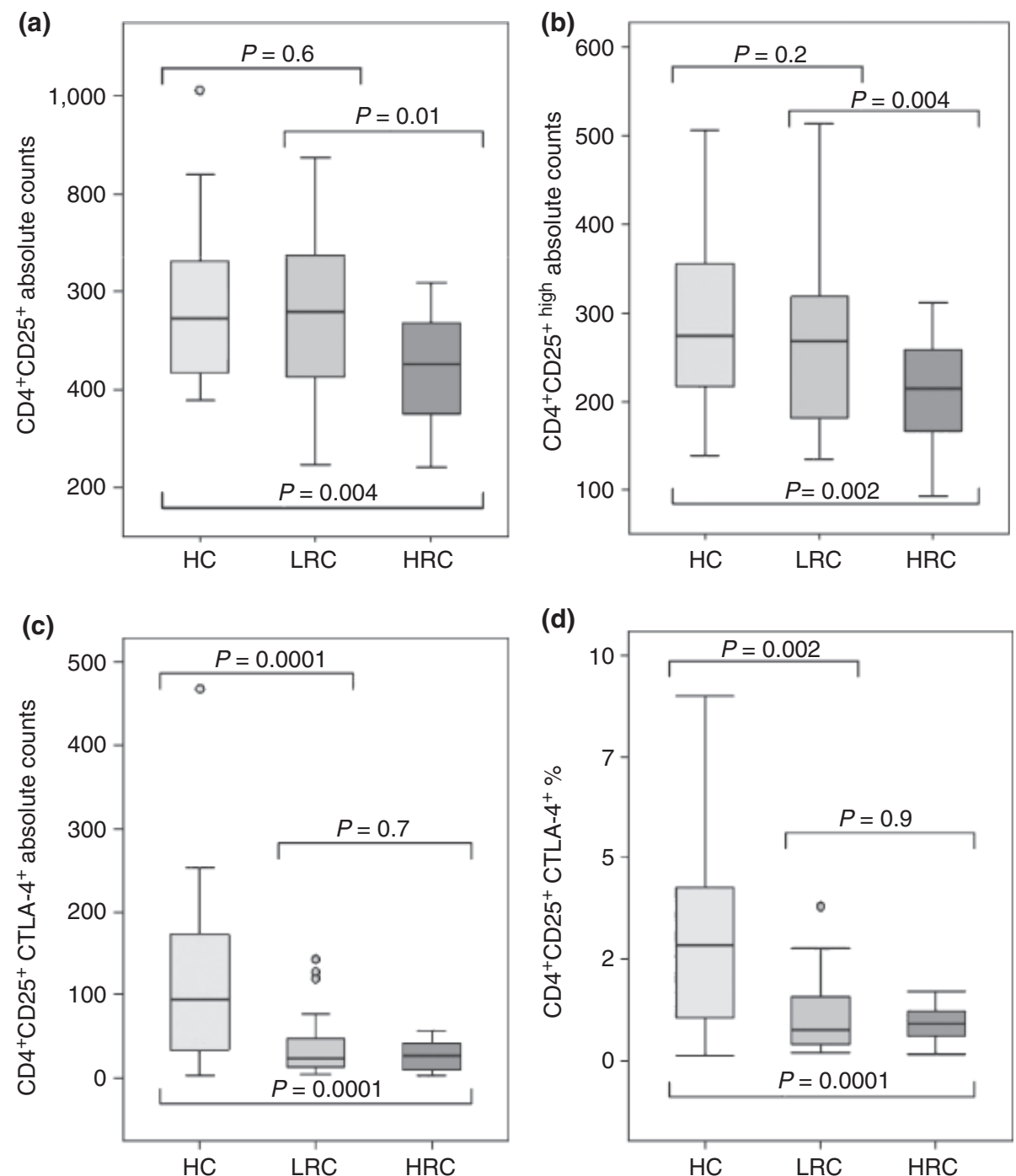

(d)
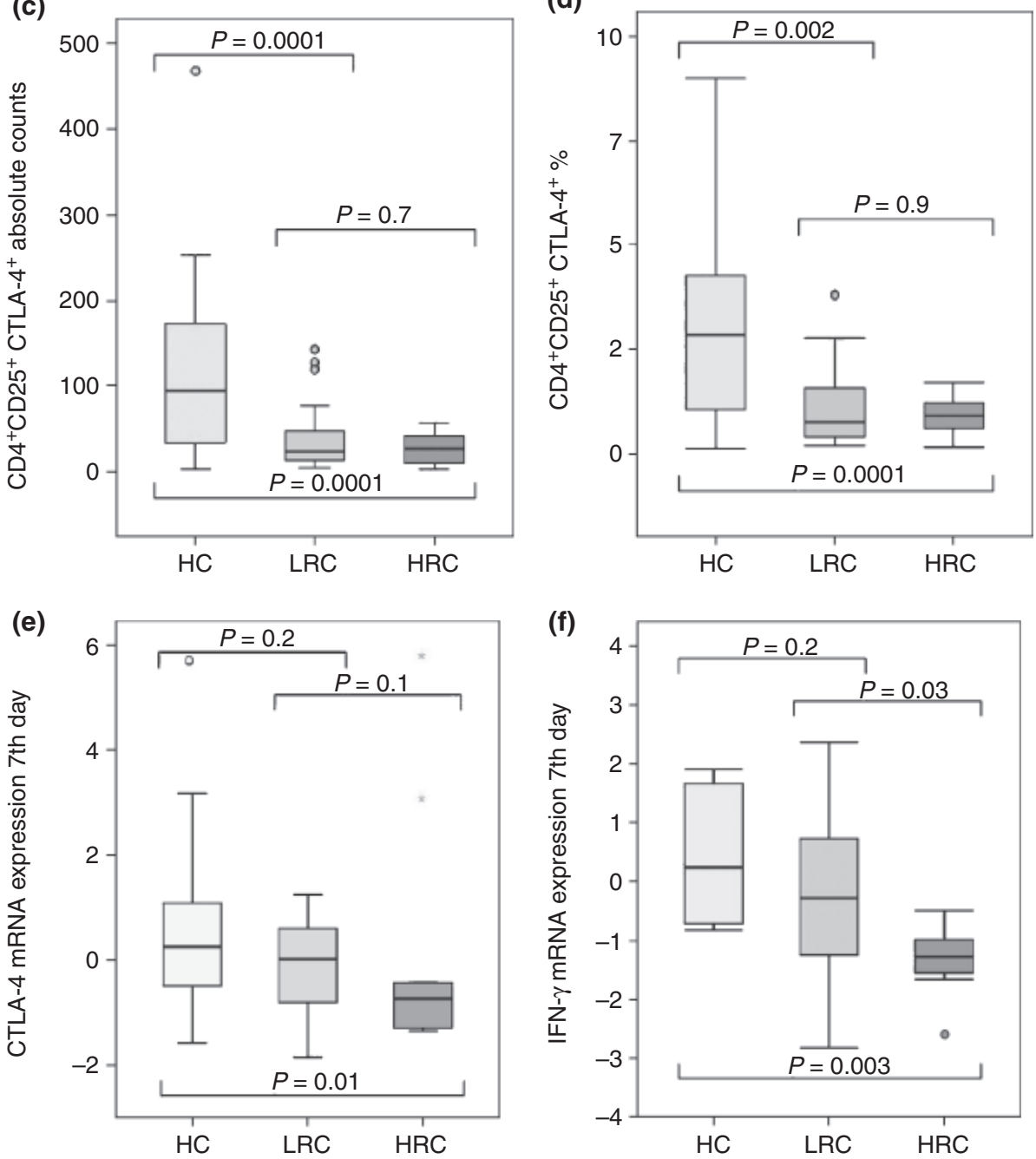

significantly higher CTLA-4 and Foxp3 mRNA expression compared with those obtained in the wheezy group (Table 2). For IFN- $\gamma$, IL-10 and TGF- $\beta$, no significant differences were found in mRNA expression (Table 2). When results

were analysed, separating high- and low-risk groups, no significant differences were found between the three groups for Foxp3, CTLA- 4 , IFN- $\gamma$, IL- 10 and TGF- $\beta$ mRNA expression (Table 3 ). 
Cytokines, cytotoxic T-lymphocyte-associated antigen-4 and Foxp 3 expression post-house dust mite extract stimulation

After the incubation period of 7 days with HDM extracts, a significantly higher expression of CTLA-4 and IFN- $\gamma$ was observed in healthy children compared with wheezy children (Table 2). However, considering high and low asthma risk groups, only the high-risk group maintained this tendency for significantly lower expression levels in both CTLA-4 and IFN- $\gamma$, when compared with healthy controls (Table 3). The low-risk group presented no significant difference in expression levels compared with the healthy controls. However, when compared with the high-risk group, they presented higher IFN- $\gamma$ mRNA expression values as shown in Table 3 and Fig. 1f. In the evaluation of the cytokine and Foxp3 expression, only IFN- $\gamma$ was significantly different between the low- and high-risk groups.

\section{Associations between recurrent wheeze and flow cytometry parameters and messenger RNA expression}

After adjusting for possible confounding factors identified by univariate analysis (i.e. sex, age and smoke exposure), the associations between flow cytometry parameters and recurrent wheeze, with a high and a low risk for asthma, were evaluated using multiple linear regression. No significant correlations were found for the parameters that had statistically significant differences between groups (percentage values of $\mathrm{CD} 4{ }^{+} \mathrm{CD} 25^{+} \mathrm{CTLA}-4^{+}$, and absolute values of $\mathrm{CD} 4{ }^{+} \mathrm{CD} 25^{+} \mathrm{CTLA}-4^{+}, \mathrm{CD} 4^{+} \mathrm{CD} 25^{+}$and $\left.\mathrm{CD} 4^{+} \mathrm{CD} 25^{\text {high }}\right)$. In the same way, associations between mRNA expression and recurrent wheeze, with a high and a low risk for asthma, were evaluated using multiple linear regression analysis, after adjusting for the same possible confounding factors identified using univariate analysis. No statistically significant associations were found for the parameters evaluated (CTLA- 4 and IFN- $\gamma$ mRNA expression).

\section{Discussion}

The main aim of this study was to characterize and establish the differences in the immunological status of children with recurrent wheeze (with high- or low-risk factors for asthma) and healthy children. No significant differences were found between children participating in the study regarding sex, age and smoke exposure (during pregnancy), which suggests that none of these factors affected the results.

Several studies have investigated the $\mathrm{CD} 4{ }^{+} \mathrm{CD} 25^{+} \mathrm{T}$ cell population, reporting its role in regulating the immune response. Regulatory pathways of $\mathrm{CD}^{+} \mathrm{CD} 25^{+} \mathrm{T}$ cells include mechanisms like cell-contact dependent suppres- sion, in which CTLA-4 molecules are involved $[17,18]$. An increase in Treg has been associated with an increased expression of CTLA-4 molecules, which seem to have an important role in the suppressor activity of those cells [20, 21]. In our study, wheezy children were not only found to have lower absolute counts of $\mathrm{CD} 4^{+} \mathrm{CD} 25^{\text {high }} \mathrm{T}$ cells but also a reduction in $\mathrm{CD} 4{ }^{+} \mathrm{CD} 25^{+}$CTLA- $4^{+}$T cells when compared with healthy children. Both low- and high-risk groups presented a reduced $\mathrm{CD} 4{ }^{+} \mathrm{CD} 25^{+} \mathrm{CTLA}-4^{+}$population (absolute and percentage values), corroborating the defective expression of regulatory molecules in wheezy children, suggesting that diminished CTLA-4 surface expression may be associated with recurrent wheeze. It should also be noted that the wheezy group had low counts of $\mathrm{CD} 4{ }^{+} \mathrm{CD} 25^{\text {high }} \mathrm{T}$ cells, which have been reported to have a primordial function as regulatory cells [22]. The finding of a reduction in $\mathrm{CD} 4{ }^{+} \mathrm{CD} 25^{+}$and $\mathrm{CD} 4^{+} \mathrm{CD} 25^{\text {high }}$ $\mathrm{T}$ cells (absolute counts) among the high-risk wheezy young children is consistent with that observed by Haddeland et al. [30], who described impaired capacity of producing Treg in neonates with a hereditary allergy risk when compared with a control group. Interestingly, lower absolute values for $\mathrm{CD} 4{ }^{+} \mathrm{CD} 25^{+}$and $\mathrm{CD} 4{ }^{+} \mathrm{CD} 25^{\text {high }} \mathrm{T}$ cells were also found in the high-risk group compared with the low-risk group. No significant differences were found when comparing the three groups for the percentage values of these populations. We speculate that, in young children, considering the limitations in sample quantities available for each subject (specifically due to age), combined with the normal low frequencies of the cells studied (rare events), the evaluation of absolute values should be preferred in detriment of percentages. Similarly, other authors found no significant statistical differences between percentage values for $\mathrm{CD}^{+} \mathrm{CD} 25^{+}$[31] and $\mathrm{CD} 4{ }^{+} \mathrm{CD} 25^{\text {high }}[27,32]$ in asthmatic children. In an animal model of asthma, Tregs have been shown to accumulate in the airway during the development of allergic inflammation [33]. Nevertheless, Hartl et al. [27] studied Treg in BAL, reporting impaired numbers and function of $\mathrm{CD} 4^{+} \mathrm{CD} 25^{\text {high }} \mathrm{T}$ cells in children with asthma compared with healthy children. In the present study, we were not able to measure $\mathrm{CD} 44^{+} \mathrm{CD} 25^{\text {high }} \mathrm{T}$ cells in the airway; therefore, we cannot speculate whether the results found in peripheral blood could constitute, or not, the mirror of the airway.

At first glance, the differences reported for $\mathrm{CD} 4^{+} \mathrm{CD} 25^{\text {high }}$ cells between groups should be similar to Foxp3 expression in these cells, as published literature has suggested that most $\mathrm{CD} 4^{+} \mathrm{CD} 25^{\text {high }}$ Treg express Foxp3 $[34,35]$, which might even differentiate them from activated cells [24]. Surprisingly, in this study, the significant differences found between the wheezy and the control groups in $\mathrm{CD} 4{ }^{+} \mathrm{CD} 25^{\text {high }}$ absolute numbers were not observed in either percentage or absolute values of Foxp3 expression in the $\mathrm{CD} 4{ }^{+} \mathrm{CD} 25^{\text {high }}$ population. Even though 
several authors have described CD25 and Foxp3 as Treg markers [36-38], activated and regulatory $\mathrm{CD} 4^{+} \mathrm{T}$ cells might have an overlapping expression of CD25 and, recently, Morgan et al. [39] reported Foxp3 expression in activated cells, after induction. In agreement, previous reports postulate that Foxp3 expression might be intermittent in Treg, and even induced, in order to promote the development of regulatory phenotypes [40]. Further work is required to clarify the associations between Foxp3, $\mathrm{CD} 4{ }^{+} \mathrm{CD} 25^{\text {high }}$ and the regulatory activity of $\mathrm{T}$ cells.

Regarding PBMC stimulation, unspecific and allergenic stimuli presented distinctive results. In the current study, after an HDM-specific stimulation, decreased mRNA expression of CTLA-4 mRNA was observed in wheezy children compared with healthy children, and also in the high-risk group compared with the healthy group. No differences were reported for Foxp3 expression after HDM stimulation. On the other hand, after PMA stimulation, the reduction in CTLA-4 and Foxp3 mRNA expression found in the wheezy group was only statistically significant when compared with the values in healthy children; no significant differences for these parameters were observed when comparing the high- and low-risk wheezy subgroups separately with the healthy group. These data are suggestive that recurrent wheeze, independent of the risk for asthma, may be associated with impaired expression of these molecules after innate stimulation. Shaub et al. [41] presented similar results, reporting no significant differences for Foxp3 and CTLA-4 expression, when comparing neonates from atopic and non-atopic mothers. In our study, mRNA expression of regulating cytokines IL-10 and TGF- $\beta$ showed no significant differences between groups for either innate (PMA) or allergenic (HDM) stimuli. TGF- $\beta$ has been reported to be a key element in Foxp3 expression [42]. Indeed, particularly in the HDM stimulus, the absence of significant differences occurred for both Foxp3 and TGF- $\beta$. However, this absence of a significant difference in TGF- $\beta$ also supports the Foxp3 findings in mRNA expression. Conflicting results have been reported in the literature regarding the findings of IL-10. After peptidoglican stimulation, Schaub et al. [41]reported no significant differences between offspring from atopic and non-atopic mothers. Other studies also reported no difference in IL-10 mRNA expression between children with a high risk and a low risk for atopic diseases, only defined by a family history of allergy, after cord blood cell stimulation with mitogenic agents [43], and no differences in IL-10 mRNA expression between asthmatic children and a control group [44]. Nevertheless, Treg producing IL-10 and Th2 cells seem to be unbalanced in atopic/allergic diseases [45].

Although IFN- $\gamma$ showed a lower expression in the entire wheezing population after HDM stimulation, it was the only parameter to discriminate between wheezy children with a high and a low risk for asthma. Some studies reported an association between decreased IFN- $\gamma$ expression and atopic diseases $[9,46,47]$. In the Tucson study [48], a decreased production of IFN- $\gamma$ in stimulated PBMC observed in infants at birth and at three months has been associated with a high risk for recurrent wheeze in the first year of life. Van der Velden et al. [49] reported no significant differences in IFN- $\gamma$ production after unspecific stimulation (as was similarly observed in the present study) but only after an allergenic stimulus in children with a high risk for atopic diseases, defined by a family history of atopy. These authors related the increased production of Th2 cytokines, after cell stimulation with allergen, to an impaired production of IFN- $\gamma$ in high-risk children, corroborating IFN $-\gamma$ as a potent Th2 response inhibitor.

The main strength of this study is that, to our knowledge, this is the first report that has compared immunological measurements, in young children with recurrent wheeze, according to their risk for asthma, using the predictive index published by Castro-Rodriguez et al. [5]. One of the limitations of this study was the absence of measurements of cytokines from the culture supernatants. These would have allowed the evaluation of cytokine expression on the protein level but these measurements were not included in this protocol as it would have prolonged the analysis process and increased the costs. Moreover, mRNA expression after cell stimulation was also applied to the evaluation of other markers (Foxp3, CTLA-4) that cannot be measured in supernatants. Another limitation is the lack of assessment of CD103/CD127 surface expression, which was recently described to differentiate Treg cell subsets [50-52].

In summary, the findings from this study suggested that children with recurrent wheeze appear to have lower absolute numbers of Treg populations $\left(\mathrm{CD} 4{ }^{+} \mathrm{CD} 25^{\text {high }}\right.$ and $\mathrm{CD} 4{ }^{+} \mathrm{CD} 25^{+} \mathrm{CTLA}_{-} 4^{+}$), and also a lower expression of CTLA-4 and IFN- $\gamma$ (after HDM stimulation) than healthy controls. However, when using the clinical index published by Castro-Rodriguez et al. [5], the only parameters that could distinguish a high risk from a low risk for asthma wheezing children were lower absolute numbers of $\mathrm{CD} 4{ }^{+} \mathrm{CD} 25^{+}$and $\mathrm{CD} 4{ }^{+} \mathrm{CD} 25^{\text {high }} \mathrm{T}$ cells and lower expression of IFN- $\gamma$ after HDM stimulation in the highrisk group.

Although the use of immunological parameters in the clinical management of young children with recurrent wheeze remains controversial, the findings from the current study may provide support for the use of such parameters in this clinical group of young children, in combination with additional clinical aspects for both diagnostic and therapeutic procedures. Indeed, a precocious identification of children with a high risk for asthma will be fundamental for starting treatments before any airway damage or irreversible airway remodelling. Longitudinal follow-up studies may provide for the importance 
of these immunological evaluations as surrogate predictor factors for asthma in early life.

\section{References}

1 Clough JB, Keeping KA, Edwards LC et al. Can we predict which wheezy infants will continue to wheeze? Am J Respir Crit Care Med 1999; 160:1473-80.

2 Martinez FD, Wright AL, Taussig LM et al. Asthma and wheezing in the first six years of life. The Group Health Medical Associates. N Engl J Med 1995; 332:133-8.

3 Taussig LM, Wright AL, Holberg CJ et al. Tucson children's respiratory study: 1980 to present. J Allergy Clin Immunol 2003; 111:661-75.

4 De Sario M, Di Domenicantonio R, Corbo G et al. Characteristics of early transient, persistent, and late onset wheezers at 9 to 11 years of age. $J$ Asthma 2006; 43:633-8.

5 Castro-Rodriguez JA, Holberg CJ, Wright AL et al. A clinical index to define risk of asthma in young children with recurrent wheezing. Am J Respir Crit Care Med 2000; 162:1403-6.

6 von Mutius E. Influences in allergy: epidemiology and the environment. J Allergy Clin Immunol 2004; 113:373-799.

7 Prescott SL, Macaubas C, Smallacombe T et al. Reciprocal agerelated patterns of allergen specific T-cell immunity in normal vs atopic infants. Clin Exp Allergy 1998; 28 (Suppl. 5):39-41, 50-1.

8 Rinas U, Horneff G, Wahn V. Interferon-gamma production by cord-blood mononuclear cells is reduced in newborns with a family history of atopic disease and is independent from cord blood Ig-E levels. Pediatr Allergy Immunol 1993; 4:60-4.

9 Tang ML, Kemp AS, Thornburn G, Hill DJ. Reduced interferongamma in neonates and subsequent atopy. Lancet 1994; 344:983-5.

10 Liao SY, Liao TN, Chiang BL et al. Decreased production of IFN gamma and increased production of IL- 6 by cord blood mononuclear cells of newborns with high risk of allergy. Clin Exp Allergy 1996; 26:397-405.

11 Scheikh A, Smeeth L, Hubbard R. There is no evidence of an inverse relationship between $T_{H} 2$ mediated atopy and $T_{H} 1$ mediated autoimmune disorders: lack of support for the hygiene hypothesis. J Allergy Clin Immunol 2003; 111:131-5.

12 Wills-Karp M, Santeliz J, Karp CL. The germless theory of allergic disease: revisiting the hygiene hypothesis. Nat Rev Immunol 2001; 1:69-75.

13 Curotto de Lafaille MAC, Lafaille JJ. CD4+ regulatory T cells in autoimmunity and allergy. Curr Opin Immunol 2002; 14:771-8.

14 Van Oosterhout AJ, Bloksma N. Regulatory T-lymphocytes in asthma. Eur Respir J 2005; 26:918-32.

15 Grindebacke H, Wing K, Anderson AC, Suri-Payer E, Rak S, Rudin A. Defective suppression of Th2 cytokines by $\mathrm{CD} 4{ }^{+} \mathrm{CD} 25^{+}$ regulatory $\mathrm{T}$ cells in birch allergics during birch pollen season. Clin Exp Allergy 2004; 34:1364-72.

16 Bellinghausen I, Klostermann B, Knop J, Saloga J. Human $\mathrm{CD} 4{ }^{+} \mathrm{CD} 25^{+} \mathrm{T}$ cells derived from the majority of atopic donors are able to supress $\mathrm{T}_{\mathrm{H}} 1$ and $\mathrm{T}_{\mathrm{H}} 2$ cytokine production. $J$ Allergy Clin Immunol 2003; 111:862-8.

17 Read S, Malmstrom V, Powrie F. Cytotoxic T lymphocyteassociated antigen 4 plays an essential role in the function of $\mathrm{CD} 25^{+} \mathrm{CD} 4{ }^{+}$regulatory cells that control intestinal inflammation. J Exp Med 2000; 192:295-302.
18 Takahashi T, Tagami T, Yamazaki S et al. Immunologic selftolerance maintained by $\mathrm{CD} 25^{+} \mathrm{CD} 4{ }^{+}$regulatory $\mathrm{T}$ cells constitutively expressing cytotoxic T lymphocyte-associated antigen 4. J Exp Med 2000; 192:303-10.

$19 \mathrm{Ng}$ WF, Duggan PJ, Ponchel F et al. Human $\mathrm{CD} 4{ }^{+} \mathrm{CD} 25^{+}$cells: a naturally occurring population of regulatory T cells. Blood 2001; 98:2736-44.

20 Tang Q, Boden EK, Henriksen KJ, Bour-Jordan H, Bi M, Bluestone JA. Distinct roles of CTLA-4 and TGF-beta in $\mathrm{CD} 4^{+} \mathrm{CD} 25^{+}$ regulatory $\mathrm{T}$ cell function. Eur $J$ Immunol 2004; 34: 2996-3005.

21 Paust S, Lu L, McCarty N, Cantor H. Engagement of B7 on effector $\mathrm{T}$ cells by regulatory $\mathrm{T}$ cells prevents autoimmune disease. Proc Natl Acad Sci USA 2004; 101:10398-403.

22 Baecher-Allan C, Brown JA, Freeman GJ, Hafler DA. $\mathrm{CD} 4^{+} \mathrm{CD} 25^{\text {high }}$ regulatory cells in human peripheral blood. J Immunol 2001; 167:1245-53.

23 Jartti T, Burmeister KA, Seroogy CM et al. Association between $\mathrm{CD} 4{ }^{+} \mathrm{CD} 25^{\text {high }} \mathrm{T}$ cells and atopy in children. J Allergy Clin Immunol 2007; 120:177-83.

24 Baecher-Allan C, Wolf E, Hafler DA. Functional analysis of highly defined, FACS isolated populations of human regulatory $\mathrm{CD}^{+}{ }^{+} \mathrm{CD} 25^{+}$T cells. Clin Immunol 2005; 115:10-8.

25 Jonuleit H, Schmitt E, Stassen M, Tuettenberg A, Knop J, Enk AH. Identification and functional characterization of human $\mathrm{CD} 4{ }^{+} \mathrm{CD} 25^{+} \mathrm{T}$ cells with regulatory propreties isolated from periphereal blood. J Exp Med 2001; 193:1258-94.

26 Roncador J, Brown PJ, Maestre L et al. Analysis of Foxp3 protein expression in human $\mathrm{CD}^{+} \mathrm{CD} 25^{+}$regulatory $\mathrm{T}$ cells at the single-cell level. Eur J Immunol 2005; 35:1681-91.

27 Hartl D, Koller B, Mehlhorn AT et al. Quantitative and functional impairment of pulmonary $\mathrm{CD} 4{ }^{+} \mathrm{CD} 25^{\text {hi }}$ regulatory $\mathrm{T}$ cells in pediatric asthma. J Allergy Clin Immunol 2007; 119:1258-66.

28 Livak KJ, Schmittgen TD. Analysis of relative gene expression data using real-time quantitative PCR and the $2^{-\Delta \Delta \mathrm{C}_{\mathrm{T}}}$ Method. Methods 2001; 25:402-8.

29 Yuan JS, Reed A, Chen F, Stewart CN Jr Statistical analysis of real-time PCR data. BMC Bioinformatics 2006; 7:85.

30 Haddeland U, Karstensen AB, Farkas L et al. Putative regulatory $\mathrm{T}$ cells are impaired in cord blood from neonates with hereditary allergy risk. Pediatr Allergy Immunol 2005; 16:104-12.

31 Shi HZ, Li S, Xie ZF, Qin XJ, Qin X, Zhong XN. Regulatory $\mathrm{CD} 4{ }^{+} \mathrm{CD} 25^{+} \mathrm{T}$ lymphocytes in peripheral blood from patients with atopic asthma. Clin Immunol 2004; 113:172-8.

32 Lin YL, Shieh CC, Wang JY. The functional insufficiency of human $\mathrm{CD}^{+} \mathrm{CD} 25^{\text {high }}$ T-regulatory cells in allergic asthma is subjected to TNF-alpha modulation. Allergy 2008; 63:67-74.

33 Strickland DH, Stumbles PA, Zosky GR et al. Reversal of airway hyperresponsiveness by induction of airway mucosal CD4+CD25+ regulatory $\mathrm{T}$ cells. J Exp Med 2006; 203: 2649-60.

34 Allan SE, Passerini L, Bacchetta R et al. The role of 2 FOXP3 isoforms in the generation of human $\mathrm{CD}^{+}{ }^{+}$Tregs. J Clin Invest 2005; 115:3276-84.

35 Ziegler SF. FOXP3: of mice and men. Annu Rev Immunol 2006; 24:209-26.

36 Fontenot JD, Gavin MA, Rudensky AY. Foxp3 programs the development and function of $\mathrm{CD} 4{ }^{+} \mathrm{CD} 25^{+}$regulatory $\mathrm{T}$ cells. Nat Immunol 2003; 4:330-6. 
37 Hori S, Nomura T, Sakaguchi S. Control of regulatory T cell development by the transcription factor Foxp3. Science 2003; 299:1057-61.

38 Reefer AJ, Satinover SM, Solga MD et al. Analysis of $\mathrm{CD} 25^{\mathrm{hi}} \mathrm{CD} 4{ }^{+}$"regulatory" $\mathrm{T}$-cell subtypes in atopic dermatitis reveals a novel $\mathrm{T}_{\mathrm{H}}$ 2-like population. J Allergy Clin Immunol 2008; 121:415-22.

39 Morgan ME, van Bilsen JH, Bakker AM et al. Expression of FOXP3 mRNA is not confined to $\mathrm{CD} 4{ }^{+} \mathrm{CD} 25^{+} \mathrm{T}$ regulatory cells in humans. Hum Immunol 2005; 66:13-20.

40 Chen W, Jin W, Hardegen $\mathrm{N}$ et al. Conversion of peripheral $\mathrm{CD} 4{ }^{+} \mathrm{CD} 25^{-}$naive $\mathrm{T}$ cells to $\mathrm{CD} 4^{+} \mathrm{CD} 25^{+}$regulatory $\mathrm{T}$ cells by TGF-beta induction of transcription factor Foxp3. J Exp Med 2003; 198:1875-86.

41 Schaub B, Liu J, H S et al. Impairmente of T-regulatory cells in cord blood of atopic mothers. J Allergy Clin Immunol 2008; 121:1491-9, 1499, e1-13.

$42 \mathrm{Fu} \mathrm{S}$, Zhang N, Yopp AC et al. TGF-beta induces Foxp3+ T-regulatory cells from CD4+CD25- precursors. Am J Transplant 2004; 4:1614-27.

43 Yang YH, Chen MC, Tsai MJ, Lin YT, Chiang BL. Costimulatory molecules expression and cytokine profiles of cord blood mononuclear cells in newborns with low and high risk of developing atopic diseases. J Microbiol Immunol Infect 2000; 33:159-64.

44 Koning H, Neijens HJ, Baert MR, Oranje AP, Savelkoul HF. T cells subsets and cytokines in allergic and non-allergic children. II. Analysis and IL-5 and IL-10 mRNA expression and protein production. Cytokine 1997; 9:427-36.
45 Akdis M, Verhagen J, Taylor A et al. Immune responses in healthy and allergic individuals are characterized by a fine balance between allergen-specific T regulatory 1 and T helper 2 cells. J Exp Med 2004; 199:1567-75.

46 Kjellman NI, Croner S. Cord blood IgE determination for allergy prediction - a follow-up to seven years of age in 1,651 children. Ann Allergy 1984; 53:167-71.

47 Kondo N, Kobayashi Y, Shinoda S et al. Reduced interferon gamma production by antigen stimulated cord blood mononuclear cells is a risk factor of allergic disorders - 6-year followup study. Clin Exp Allergy 1998; 28:1340-4.

48 Guerra S, Lohman IC, Halonen M, Martinez FD, Wright AL. Reduced interferon gamma production and soluble CD14 levels in early life predict recurrent wheezing by 1 year of age. $\mathrm{Am}$ J Respir Crit Care Med 2004; 169:70-6.

49 van der Velden V, Laan MP, Baert MR, de Waal Malefyt R, Neijens HJ, Savelkoul HF. Selective development of a strong Th2 cytokine profile in high-risk children who develop atopy: risk factors and regulatory role of IFN-gamma, IL-4 and IL-10. Clin Exp Allergy 2001; 31:997-1006.

50 Allakhverdi Z, Fitzpatrick D, Boisvert A et al. Expression of CD103 identifies human regulatory T-cell subsets. J Allergy Clin Immunol 2006; 118:1342-9.

51 Liu W, Putnam AL, Xu-Yu Z et al. CD127 expression inversely correlates with FoxP3 and suppressive function of human CD41 T reg cells. J Exp Med 2006; 203:1701-11.

52 Seddiki N, Santner-Nanan B, Martinson J et al. Expression of interleukin (IL)-2 and IL-7 receptors discriminates between human regulatory and activated T cells. J Exp Med 2006; 203:1693-700. 